Document downloaded from:

http://hdl.handle.net/10251/102180

This paper must be cited as:

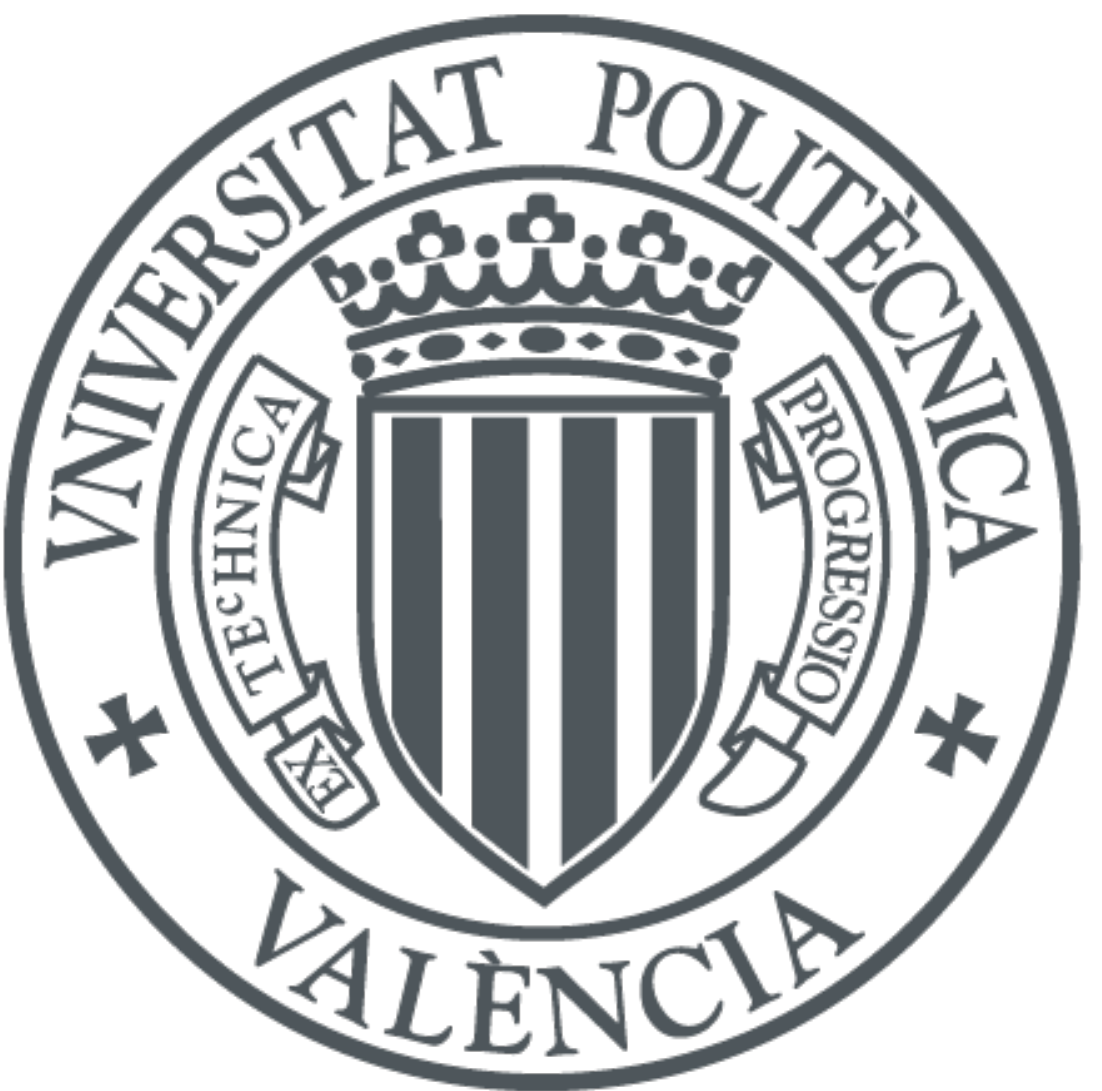

The final publication is available at

https://doi.org/10.1007/s11947-017-2019-8

Copyright Springer-Verlag

Additional Information 


\title{
NEW SPECTROPHOTOMETRIC SYSTEM TO SEGREGATE TISSUES IN MANDARIN FRUIT
}

Maria Victoria Traffano-Schiffo ${ }^{1}$, Marta Castro-Giraldez ${ }^{1 *}$, Ricardo J. Colom ${ }^{2}$, Pedro J. Fito ${ }^{1}$

${ }^{1}$ Instituto Universitario de Ingeniería de Alimentos para el Desarrollo, Universitat Politecnica de Valencia, Camino de Vera s/n, 46022, Valencia, Spain.

${ }^{2}$ Instituto de Instrumentación para Imagen Molecular, Universitat Politecnica de Valencia, Valencia, Spain.

*Corresponding author:

Phone: +34 636998785; fax: +34 963879832 .

e-mail: marcasgi@upv.es

\begin{abstract}
The knowledge of the electrical properties of the fruit tissues and their relation with the structural and compositional properties opens an endless number of opportunities in the development and design of industrial equipment for quality and process control. Nowadays, one of the main industrial issues is the detection of seeds inside the fruit, which could be possible with an electrical study of each tissue as a first step of the development of non-destructive sensors. In this context, a deep study of the dielectric properties of mandarin fruit tissues, coupled with $\mathrm{a}_{\mathrm{w}}, \mathrm{X}_{\mathrm{w}}, \mathrm{pH}$, maturity index, Cryo-SEM and optical measurements were performed. Dielectric properties were studied in radiofrequency and microwave ranges. $\alpha, \beta$ and $\gamma$-dispersions and their relaxation parameters were obtained, described and related to the chemical parameters. Finally, a tool, based on the relaxation dielectric constant in $\gamma$-dispersion able to determine the moisture content of the mandarin fruit tissues, has been developed.
\end{abstract}

Keywords: mandarin fruit, spectrophotometry, radiofrequency, microwave, dispersions, microstructure.

\section{Introduction}

During the last decade, there has been a continuous increase in the consumption and demand of citrus fruits in the international market, being the mandarin fruit the one that shows the greater growth (Liu et 
al. 2012). The consumption habits promoted by a healthy diet and the nutritional qualities are some of the elements that explain this trend (Mateus-Cagua and Orduz-Rodríguez 2015).

Histologically, mandarin fruit, as all citrus fruits, consists in three parts: peel, pulp and seed. The outer part of the peel is made up of an epidermis commonly called exocarp or flavedo and the inner part is the mesocarp or albedo. The albedo consists in vascular bundles, which are distributed along the pulp (Liu et al. 2012). The endocarp is the innermost part of the fruit and it is composed by carpels or locules (pulp) covered by slightly thick layer of vascular bundles (Goldschmidt 1988), which have a large number of juice vesicles. It is important to highlight that each tissue has different functionality, structure and composition.

Regarding the composition, mandarin tissues show big differences in the content of ions, essential oils, sugars, fiber content and principally, water. It should be taken into account that each of the components aforementioned show different electric properties, which provide valuable information such as physical, chemical and compositional properties. Due to this, a spectrophotometric analysis able to describe the electric behavior of each tissue represents a first step in the development and design of industrial equipment with different applications.

Permittivity $(\varepsilon)$ is the physical property which describes the interaction between the materials such as foodstuffs and a photon flux (Traffano-Schiffo et al. 2014). Expressed as a complex number, the real part of the $\varepsilon$ is called dielectric constant ( $\left.\varepsilon^{\prime}\right)$ and it is related to the material's ability to store energy, and the imaginary part, called dielectric loss factor $(\varepsilon ")$ represents the energy fraction which is absorbed or dissipated (Talens et al. 2016). Along the electric spectrum between radiofrequency (RF) and microwaves (MW), three main dispersions can be observed: $\alpha$ and $\beta$ dispersion in radiofrequency range and $\gamma$ in microwave range (Schwan 1957).

$\alpha$-dispersion (from a few $\mathrm{Hz}$ to a few $\mathrm{kHz}$ ) is induced by the orientation of mobile charges in a dielectric medium (Traffano-Schiffo et al. 2017a). $\beta$-dispersion (from $\mathrm{kHz}$ to tens of $\mathrm{MHz}$ ) is related to the orientation of fixed charges in macromolecules such as proteins and carbohydrates, and it could explain complex conformations of these molecules. At higher frequencies of $\beta$-dispersion the main effect is the surface tension; this phenomenon is called Maxwell-Wagner effect (Traffano-Schiffo et al. 2017a,b). In MW range, the interaction of the electric field with biological tissue produces the $\gamma$-dispersion. It is observed at $\mathrm{GHz}$ frequencies and it is due to the dipolar molecules (mainly water) orientation and 
induction (Castro-Giráldez et al. 2011; Gabriel et al. 1996). Other important effect in microwave range is ionic conductivity at frequencies from $\mathrm{Hz}$ to $\mathrm{MHz}$ (Traffano-Schiffo et al. 2015). The application of a photon flux to biological tissue causes vibration of ions increasing the internal energy of the molecules, therefore, the ionic conductivity only affects to the loss factor (Castro-Giráldez et al. 2010; CastroGiráldez et al. 2013).

The aim of this research is to determine the electric properties of mandarin fruit tissues in order to characterize them. This study represents a first step in the development of a method for detecting seeds inside mandarin fruit with a non-destructive method.

\section{Material and methods}

\section{Material}

Fresh mandarins (Citrus clementina) obtained from a plantation located in Algimia de Alfara, Valencia, Spain were used in this experiment. Mandarins were selected according to their homogeneity in size and color and stored at $8^{\circ} \mathrm{C}$ until further usage.

\section{Experimental Procedure}

20 samples were used for the experiments. Fruits were tempered at $25^{\circ} \mathrm{C}$ and the tissues (pulp, peel and seed) were separated and maintained in aqualab ${ }^{\circledR}$ disposable sample cups, sealed with parafilm ${ }^{\circledR}$ in order to avoid water losses. The tegument of the seeds was removed in order to avoid measurement errors due to adsorbed water to the tegument that comes from the pulp. After that, physicochemical, structural and permittivity determinations were performed. Permittivity was measured in RF range by using two sensors which consist on two plate electrodes (developed by the authors). In MW range a coaxial probe (Agilent) was used.

\section{Physicochemical determinations}

The $\mathrm{pH}$ of the pulp was measured by using a punch pH-meter S-20 SevenEasy ${ }^{\mathrm{TM}}$ (Mettler Toledo, Barcelona, Spain). A dew point Hygrometer Decagon (Aqualab ${ }^{\circledR}$, series 3 TE) with a precision of \pm 0.003 was used to determine the water activity $\left(a_{w}\right)$ at $25^{\circ} \mathrm{C}$ of each mandarin tissue. Moisture of each tissue was determined by drying in a vacuum oven at $60^{\circ} \mathrm{C}$ until constant weight was reached (AOAC 2000). 
Soluble solids content of the pulp liquid phase was determined by measuring the refractometric index ( ${ }^{\circ}$ Brix) with a refractometer (ABBE, ATAGO Model 3-T, Japan) calibrated with distilled water at $25^{\circ} \mathrm{C}$. Titratable acidity, expressed as citric acid in $100 \mathrm{~mL}$ of juice, was analyzed following AOAC Method 934.06 titrating an aliquot of juice with $0.1 \mathrm{~N} \mathrm{NaOH}$ (AOAC 2000).

Analytical determinations described above were obtained in triplicate.

Finally, maturity index (MI) was calculated by dividing the soluble solids content of the extractable juice by its titratable acidity (Melgarejo et al. 2017; Alférez et al. 2005).

\section{Structural analysis}

Low-temperature scanning electron microscopy (Cryo-SEM).

The microstructure of each fruit tissue was analyzed by Cryo-SEM. A Cryostage CT-1500C unit (Oxford Instruments, Witney, UK), coupled to a Jeol JSM-5410 scanning electron microscope (Jeol, Tokyo, Japan), was used. The sample was immersed in slush $\mathrm{N}_{2}\left(-210^{\circ} \mathrm{C}\right)$ and then quickly transferred to the Cryostage at $1 \mathrm{kPa}$ where sample fracture took place. The sublimation (etching) was carried out at $-95^{\circ} \mathrm{C}$. The final point was determined by direct observation in the microscope, working at $5 \mathrm{kV}$. Then, once again in the Cryostage unit, the sample was coated with gold in vacuum $(0.2 \mathrm{kPa})$, applied for $3 \mathrm{~min}$, with an ionization current of $2 \mathrm{~mA}$. The observation in the scanning electron microscope was carried out at 20 $\mathrm{kV}$, at a working distance of $15 \mathrm{~mm}$ and a temperature $\leq-130^{\circ} \mathrm{C}$.

Optical measurements

Optical measurements of each fruit tissue were made by a binocular loupe Leica MZ APOTM (Leica Microsystems, Wetzlar, Germany) with low magnification (8x to 80x) using incident light illumination (light reflected off the surface of the sample). It uses two separate optical paths with two objectives and two eyepieces to provide slightly different viewing angles to the left and right eyes. In this way, it allows a three-dimensional visualization of the sample.

\section{Permittivity Measurements}

Radiofrequency range

Two different non-destructive sensors developed by The Institute of Food Engineering for Development (IuIAD) and The Institute for Molecular Imaging Technologies (I3M), both at the Polytechnic University 
of Valencia (Spain) were used to measure the permittivity in radiofrequency range. Sensors consist of two flat plates electrodes with different dimensions of the plates (Figure 1a), which were connected to an impedance analyzer Agilent 4294A (Agilent, Santa Clara, CA, USA). The measured frequency range was from $40 \mathrm{~Hz}$ to $1 \mathrm{MHz}$. Calibration of the equipment was performed in open (air) and short-circuit.

The signal obtained by the Agilent analyzer is the impedance Z, which was transformed to permittivity as was described by Traffano-Schiffo et al. (2017a).

\section{Microwave range}

Permittivity in microwave range was measured from $500 \mathrm{MHz}$ to $20 \mathrm{GHz}$ with an Agilent $85070 \mathrm{E}$ openended coaxial probe (Agilent, Santa Clara, CA, USA) (Figure 1b) connected to an Agilent E8362B Vector Network Analyzer (Agilent, Santa Clara, CA, USA). The system was calibrated using three different types of loads: open (air), short-circuit and $25{ }^{\circ} \mathrm{C}$ Milli ${ }^{\circledR}-\mathrm{Q}$ water. Once the calibration was carried out, $25^{\circ} \mathrm{C}$ Milli ${ }^{\circledR}-\mathrm{Q}$ water was measured again to check calibration suitability.

Permittivity measurements were performed in triplicate.

Fig. 1 Schematic representation of the sensors used at different frequency ranges. a. radiofrequency and b. microwave

\section{Statistical analysis}

The statistical analysis was carried out with the Statgraphics Centurion XVI Software (Statgraphics, Warrenton, VA, USA). One-Way ANOVA analyses were made in order to find statistically significant differences between the parameters studied for the different samples. The logistic model developed by Traffano-Schiffo and co-workers was used in order to fit the dielectric constant spectra by using nonlinear regression (Traffano-Schiffo et al. (2017a).

\section{Results and discussion}

The macro and microstructural analysis of mandarin fruit can be observed in Figure 2, where big differences among the different types of tissues can be appreciated. Firstly, the peel is composed by the flavedo, which is the outer part of the peel, and the albedo, the inner part. The flavedo is constituted by 
the epidermis which is covered by a cuticle, while inward parenchymatic cells can be appreciated. The parenchymatic cells are isodiametric and have spherical or oval shapes with very compacted structure, where practically does not exist intercellular spaces and thus the liquid phase inside is very low. These cells are found below the epidermis and surrounding oil glands cavities (trichomes). Furthermore, the importance of flavedo is that it contains the stomas, which are cellular complex responsible for the gas exchange between the interior and exterior of the fruit. Therefore, the flavedo shows various functions, first the outer part or cuticle reduces the water exchange with the outside, maintaining high internal water activity, and on the other hand, the stomas (indicated by an arrow) are surrounded by two cells defined as guard or occlusive cells, which regulate the opening of the stoma by integrating different signals (endogenous or exogenous). Proper stoma regulation provides an efficient use of water and optimum $\mathrm{CO}_{2}$ exchange rate (Ladanyia, 2008).

The albedo is the inner and white part of the peel and it consists in meristematic cells, with irregular shape and size and with large air gaps. The cells have tubular geometry, which are interconnected with large intercellular spaces. Macroscopically, tubular geometry can be correlated with a spongy structure, free of turgidity and compartmentalization. With regard to the pulp, it is composed by lengthened cells called vesicles, where most of its space is occupied by vacuoles, which contain the majority of the liquid phase of the system (juice reservoir) and where the sugars and the organic acids, such as citric acid produced during the ripening, are stored. Finally, seed cells show a very tightly packed structure with very low liquid phase.

Fig. 2 Overview of the macro and microstructure of mandarin

It should be taken into account that the physicochemical parameters greatly affect the electrical properties, so, in Table 1 these parameters, segregated according to the MI of the fruits, can be observed. Both the moisture and the water activity show significant differences $(p<0.05)$ between the tissues.

The dielectric properties of a biological tissue result from the interaction between its constituents at cellular and molecular level and the photon flux (Kuang and Nelson 1998). Permittivity was measured in $\mathrm{RF}$ and MW ranges, however, one of the main problems to fit the full spectrum is the appearance of three 
dispersions $(\alpha, \beta$ and $\gamma)$ on a very large frequency range with sigmoidal shape. Traffano-Schiffo et al. (2017a) developed a modified Gompertz model to describe the dielectric constant spectra. This model allows determining the dielectric constants and the relaxation frequencies of each dispersion (Tables 2 and 3, respectively). Relaxation parameters are important because they allow characterizing the dielectric behavior of biological tissues (Traffano-Schiffo et al. 2017b). Figure 3 shows the average data obtained for the three characteristic dispersions of the different types of mandarin tissues.

Fig. 3 Dielectric constant spectra of the different mandarin tissues. Where: the lines correspond to the values of the mathematical model and the points to the average of the experimental data. $(-)$ corresponds to the pulp, (-) the peel and (-) the seed

As Figure 3 and Table 2 show, the dielectric constant of the pulp is higher than those of the peel and the seed along the spectrum. Particularly, in $\alpha$-dispersion the dielectric constant of relaxation of the pulp shows a significant higher value $(p<0.05)$ than the other tissues due to the fact that the pulp is rich in electrolytes such as $\mathrm{Ca}^{2+}, \mathrm{Mg}^{2+}, \mathrm{K}^{+}, \mathrm{Na}^{+}, \mathrm{Fe}^{3+}, \mathrm{Cu}^{2+}, \mathrm{Mn}^{2+}$ and $\mathrm{Zn}^{2+}$ (Pérez-López et al. 2007) (with high mobility) and highly electronegative organic acids (citric and ascorbic acids) (Traffano-Schiffo et al. 2016; 2017c; 2017d); all solved in liquid phase, which increase the dielectric constant of relaxation. In contrast, in both peel and seed, the ion content with mobility is low, thus the signal decreases considerably and no significant differences between both samples can be appreciated (Table 2). However, the relaxation frequency in this spectrum range (Table 3) shows significant differences among all the tissues $(p<0.05)$, which means that the use of the relaxation frequency in $\alpha$-dispersion could represent a useful tool for tissue differentiation.

With regard to $\beta$-dispersion, there are no significant differences $(p<0.05)$ between seed and peel in terms of the dielectric constant of relaxation (Table 2). $\beta$-dispersion can be understood by the orientation of the fixed charges of proteins or carbohydrates which have active sites and orientation capacity (TraffanoSchiffo et al. 2017a). The seeds are composed by proteins (in low proportions) and the peel presents high carbohydrates content, however it seems that they do not present orientation capacity, thus the signal in 
both cases is low. In addition, the only samples that show significant differences $(p<0.05)$ in $\beta$-relaxation frequency are peel and pulp (Table 3).

Finally, in the spectrum range of the $\gamma$-dispersion, significant differences $(p<0.05)$ in the dielectric relaxation constant between the three types of tissues can be observed (Table 2). As was explained in the introduction, $\gamma$-dispersion is related with the orientation and induction of dipolar molecules (water) and as Table 1 shows there are significant differences in moisture and water activity for all samples $(p<0.05)$, being the pulp the one which presents the highest values and the seed, the lowest. In addition, also the micrographies (Figure 2) show differences in water content among tissues. Thus, microwave range can be considered as the optimum range to differentiate mandarin tissues and therefore, a deep analysis is needed.

Taking into account the imaginary part of the permittivity, the dielectric loss factors of the different mandarin tissues are shown in Figure 4. At low frequencies of the microwave range, the effect of the ionic conductivity can be appreciated. Ionic conductivity produces vibration of charged molecules; therefore, it only produces electrical energy losses (Talens et al. 2016; Castro-Giráldez et al. 2010). It should be noted that the pulp presents the highest ionic effect due to the high ions concentration (PérezLópez et al. 2007) which generate vibrations when the tissue is subjected to an external electric field (Traffano-Schiffo et al. 2015).

Fig. 4 Dielectric loss factor in MW ranges. Where: $(\Delta)$ corresponds to the pulp, $(\bullet)$ the peel and $(\diamond)$ the seed

Figure 5 shows the relations between the logarithm of the moisture in dry basis and the dielectric constant in $\gamma$-relaxation, where it is possible to observe a linear relation between both parameters $\left(\mathrm{R}^{2}=0.948\right)$. Therefore, the relaxation dielectric constant in $\gamma$-dispersion is a useful tool to predict the moisture in dry basis by using dielectric spectroscopy. 
Fig. 5 Evolution of the relaxation dielectric constant in $\gamma$-dispersion with regard to the moisture for the different tissues. Where: $(\Delta)$ corresponds to the pulp, $(\bullet)$ the peel and $(\diamond)$ the seed

\section{Conclusions}

It is possible to study deeply all mandarin tissues at macroscopic and microscopic level, to understand and to relate the structure with physicochemical and electric properties. The relaxations parameters (dielectric constant and frequency) of each tissue in $\alpha, \beta$ and $\gamma$-dispersions are obtained. Finally, a tool based on the relaxation dielectric constant in $\gamma$-dispersion, able to determine the moisture of the samples in dry basis, is developed.

This investigation work represents a valuable first step in the design and development of non-invasive and on-line sensors for detecting seeds inside the mandarin fruit based on a spectrophotometric analysis at microwave range.

\section{Acknowledgements}

The authors acknowledge the financial support from: the Spanish Ministerio de Economía, Industria y Competitividad, Programa Estatal de I+D+i orientada a los Retos de la Sociedad AGL2016-80643-R, Agencia Estatal de Investigación (AEI) and Fondo Europeo de Desarrollo Regional (FEDER). Maria Victoria Traffano Schiffo wants to thank the FPI Predoctoral Program of the Universidad Politécnica de Valencia for its support. The authors would like to thank the Electronic Microscopy Service of the Universidad Politécnica de Valencia for its assistance in the use of Cryo-SEM and also Multiscan Technologies S.L. for their support.

\section{References}

Alférez, F., Sala, J.M., Sanchez-Ballesta, M.T., Mulas, M., Lafuente, M.T., Zacarias, L. (2005). A comparative study of the postharvest performance of an ABA-deficient mutant of oranges: I. Physiological and quality aspects. Postharvest Biology and Technology, 37(3), 222-231.

AOAC, (2000). AOAC, Association of Official Analytical Chemist Official Methods of Analysis. Washington, D.C. 
Castro-Giráldez, M., Fito, P.J., Chenoll, C., Fito, P. (2010). Development of a dielectric spectroscopy technique for determining key chemical components of apple maturity. Journal of Agricultural and Food Chemistry, 58(6), 3761-3766.

Castro-Giráldez, M., Fito, P.J., Fito, P. (2010). Application of microwaves dielectric spectroscopy for controlling pork meat (Longissimus dorsi) salting process. Journal of Food Engineering, 97(4), 484-490.

Castro-Giráldez, M., Fito, P.J., Fito, P. (2011). Application of microwaves dielectric spectroscopy for controlling long time osmotic dehydration of parenchymatic apple tissue. Journal of Food Engineering, 104(2), 227-233.

Castro-Giráldez, M., Fito, P.J., Ortolá, M.D., Balaguer, N. (2013). Study of pomegranate ripening by dielectric spectroscopy. Postharvest Biology and Technology, 86, 346-353.

Gabriel, S., Lau, R.W., Gabriel, C. (1996). The dielectric properties of biological tissues: III. Parametric models for the dielectric spectrum of tissues. Physics in Medicine and Biology, 41(11), 2271.

Goldschmidt, E.E. (1988). Regulatory aspects of chloro-chromoplast interconversions in senescing Citrus fruit peel. Israel Journal of Botany, 37(2-4), 123-130.

Kuang, W., Nelson, S.O. (1998). Low-frequency dielectric properties of biological tissues: a review with some new insights. Transactions of the ASAE-American Society of Agricultural Engineers, 41(1), 173184.

Ladanyia, M. S. (2008). Citrus fruit: biology, technology and evaluation. USA: Academic Press.

Liu, Y., Heying, E., Tanumihardjo, S.A. (2012). History, global distribution, and nutritional importance of citrus fruits. Comprehensive Reviews in Food Science and Food Safety, 11(6),530-545.

Mateus-Cagua, D., Orduz-Rodríguez, J.O. (2015). Mandarina Dancy: una nueva alternativa para la citricultura del piedemonte llanero de Colombia. Corpoica Ciencia y Tecnología Agropecuaria, 16, 105112.

Melgarejo, P., Legua, P., Pérez-Sarmiento, F., Martínez-Font, R., Martínez-Nicolás, J.J., Hernández, F. (2017). Effect of a New Remediated Substrate on Fruit Quality and Bioactive Compounds in Two Strawberry Cultivars. Journal of Food and Nutrition Research, 5, 579-586. 
Pérez-López, A.J., López-Nicolás, J.M., Carbonell-Barrachina, A.A. (2007). Effects of organic farming on minerals contents and aroma composition of Clemenules mandarin juice. European Food Research and Technology, 225(2), 255-260.

Schwan, H.P. (1957). Electrical properties of tissue and cell suspensions. Advances in Biological and Medical Physics, 5, 147.

Talens, C., Castro-Giraldez, M., Fito, P.J. (2016). Study of the effect of microwave power coupled with hot air drying on orange peel by dielectric spectroscopy. LWT-Food Science and Technology, 66, 622628.

Traffano-Schiffo, M.V., Balaguer, N., Castro-Giráldez, M., \& Fito, P.J. (2014). Emerging Technologies in Fruit Juice Processing. In A. Ibartz, V. Falguera (Eds), Juice processing: Quality, safety and valueadded opportunities (pp. 197-212). Boca Raton: CRC Press.

Traffano-Schiffo, M.V., Castro-Giraldez, M., Colom, R.J., Fito, P.J. (2017a). Development of a Spectrophotometric System to Detect White Striping Physiopathy in Whole Chicken Carcasses. Sensors, $17(5), 1024$

Traffano-Schiffo, M.V., Castro-Giraldez, M., Colom, R.J., Fito, P.J. (2017b). Innovative spectrophotometric system to determine chicken meat quality. Innovative Food Science and Emerging Technologies.

Traffano-Schiffo, M.V., Castro-Giraldez, M., Colom, R.J., Fito, P.J. (2015). Study of the application of dielectric spectroscopy to predict the water activity of meat during drying process. Journal of Food Engineering, 166, 285-290.

Traffano-Schiffo, M.V., Laghi, L., Castro-Giraldez, M., Tylewicz, U., Rocculi, P., Ragni, L., Dalla Rosa, M., Fito, P.J. (2017c). Osmotic dehydration of organic kiwifruit pre-treated by pulsed electric fields and monitored by NMR. Food Chemistry, 236, 87-93. https://doi.org/10.1016/j.foodchem.2017.02.046

Traffano-Schiffo, M.V., Laghi, L., Castro-Giraldez, M., Tylewicz, U., Romani, S., Ragni, L., Dalla Rosa, M., Fito, P.J. (2017d). Osmotic dehydration of organic kiwifruit pre-treated by pulsed electric fields: Internal transport and transformations analyzed by NMR. Innovative Food Science and Emerging Technologies, 41, 259-266. 
Traffano-Schiffo, M.V., Tylewicz, U., Castro-Giraldez, M., Fito, P.J., Ragni, L., Dalla Rosa, M. (2016). Effect of pulsed electric fields pre-treatment on mass transport during the osmotic dehydration of organic kiwifruit. Innovative Food Science and Emerging Technologies, 38, 243-251. 
a.

\section{Radiofrequency}

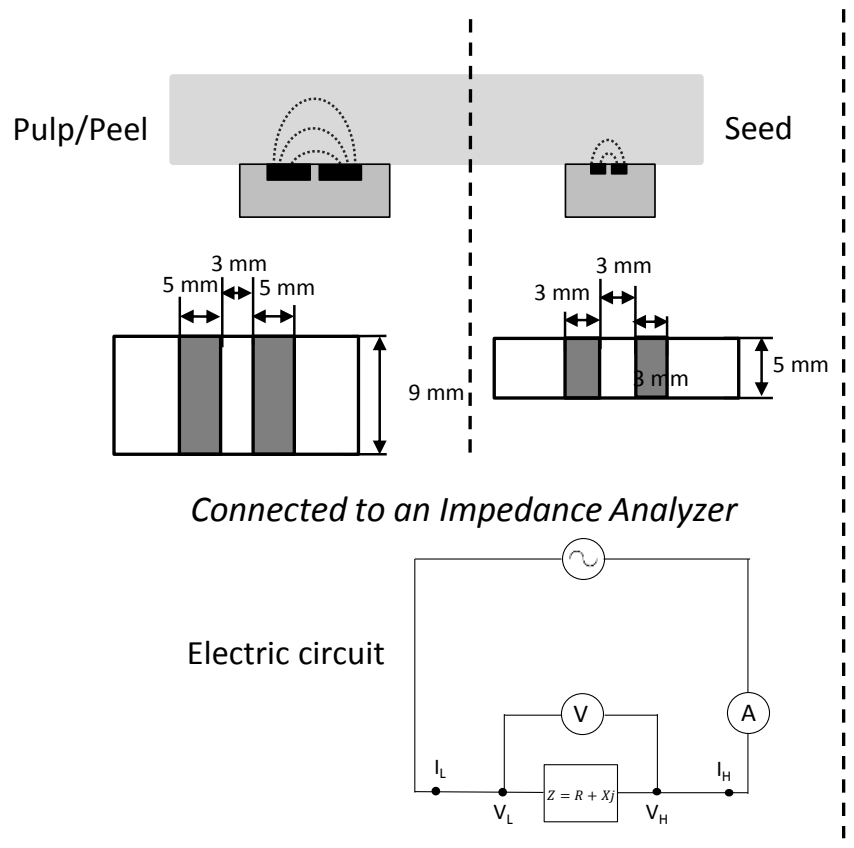

Microwave

b.

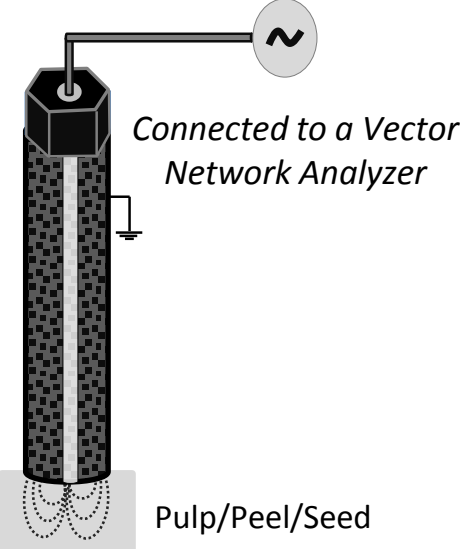

Fig. 1 


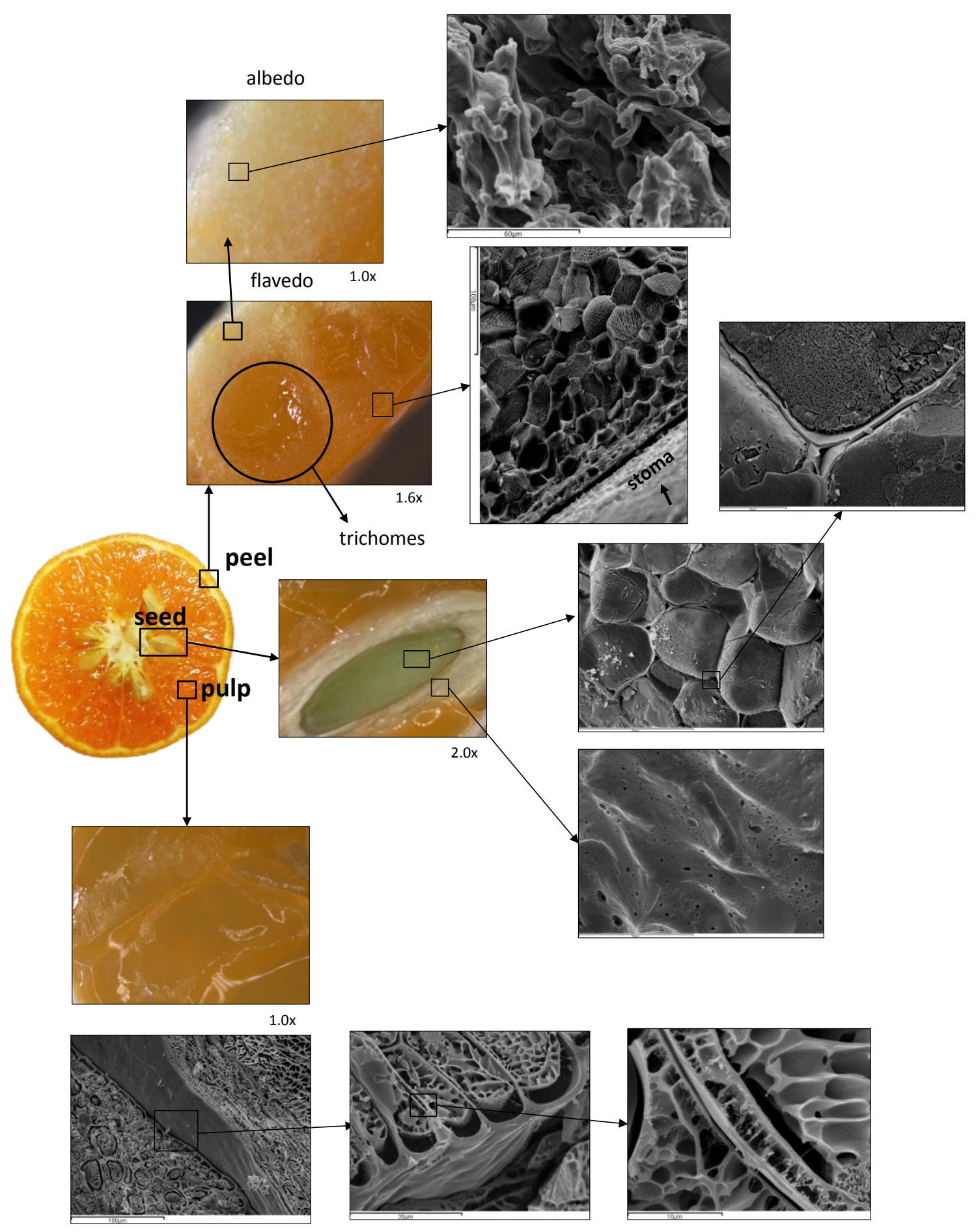

Fig. 2 


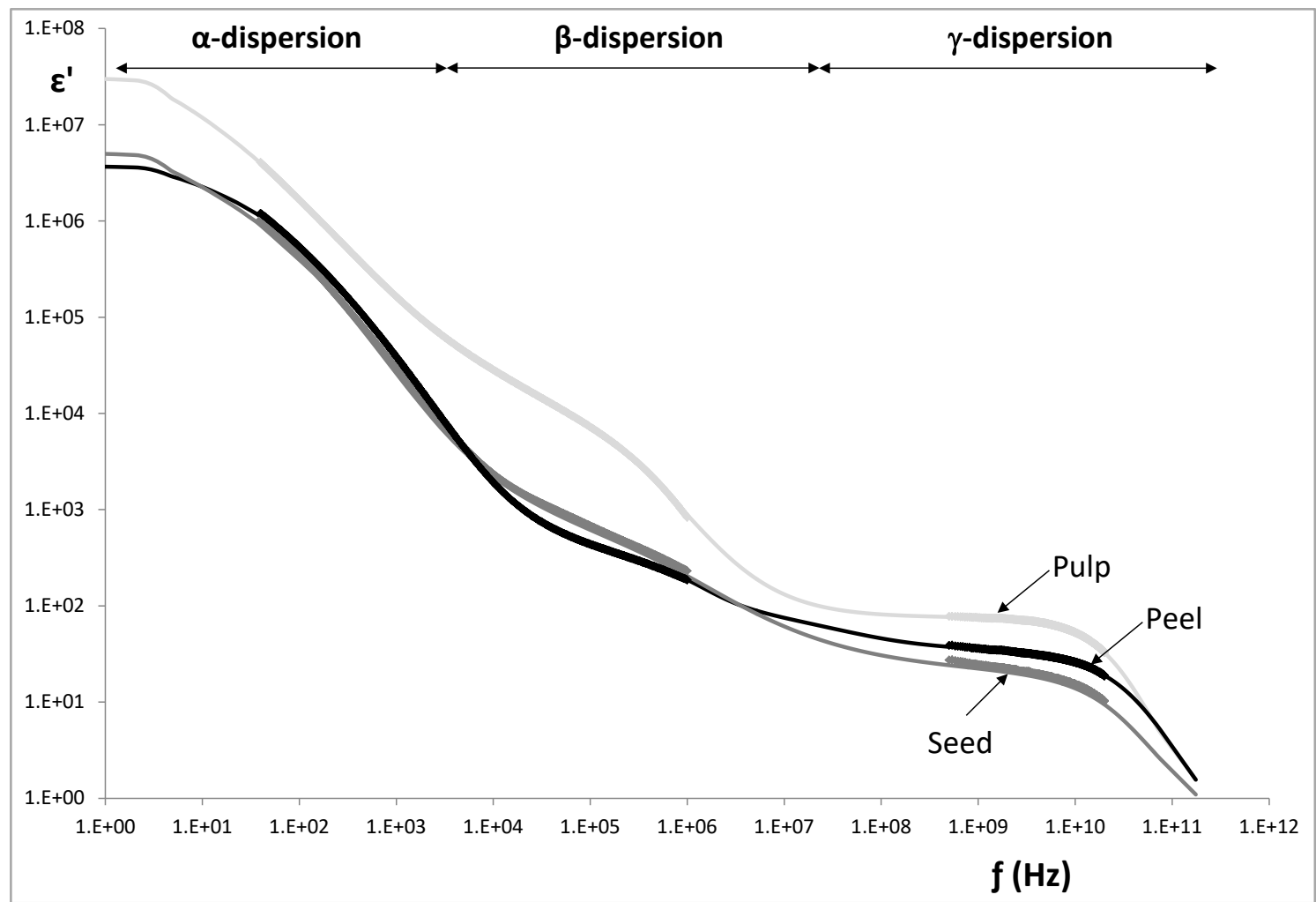

Fig. 3 


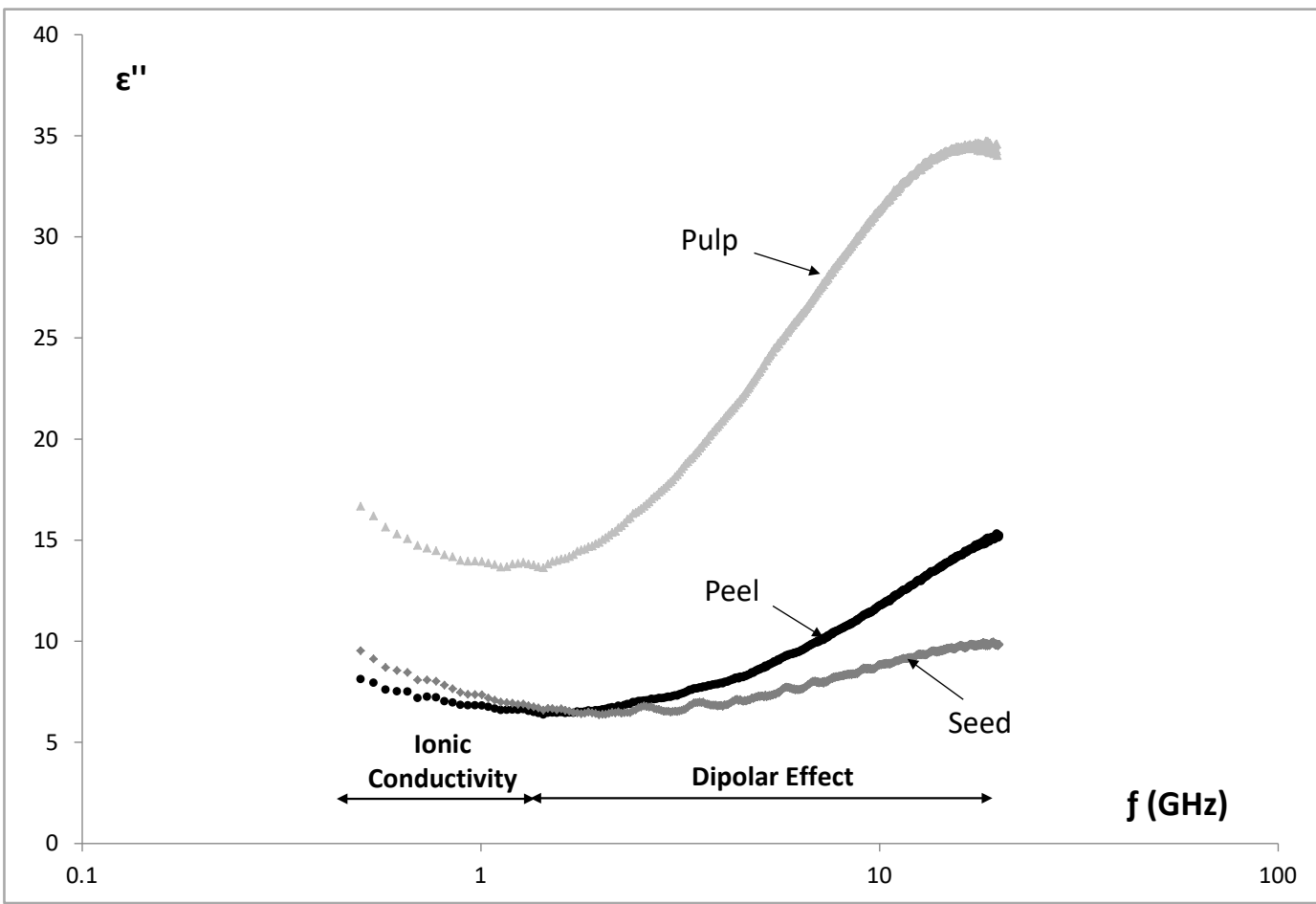

Fig. 4 


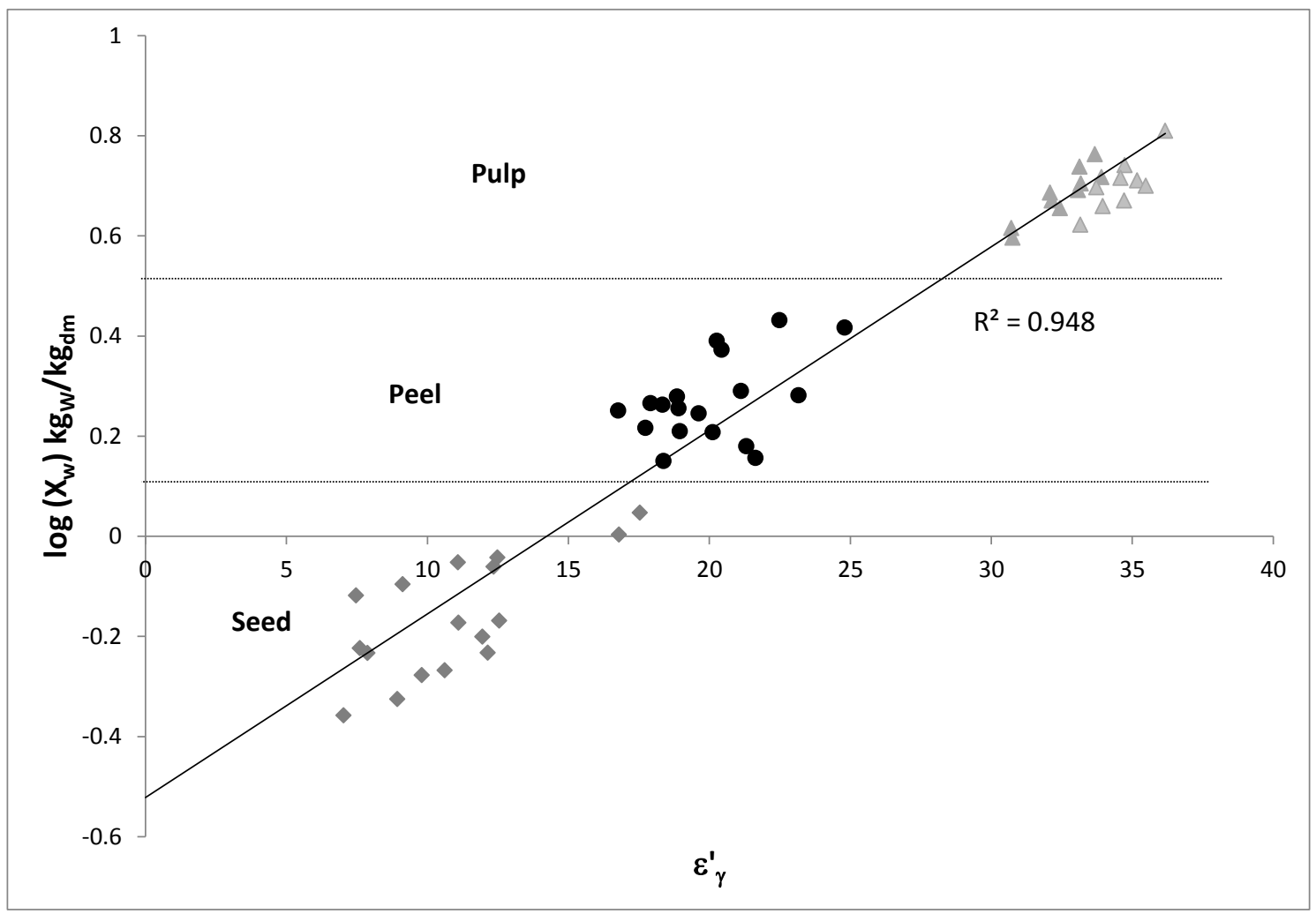

Fig. 5 
Table 1. Physicochemical parameters of each mandarin tissue according to its maturity index (MI).

\begin{tabular}{|c|c|c|c|c|c|c|c|c|}
\hline MI & Tissue & pH & \multicolumn{3}{|c|}{$X_{w}\left(k_{w w} / k_{d m}\right)$} & \multicolumn{3}{|c|}{$\mathbf{a}_{\mathbf{w}}$} \\
\hline \multirow{3}{*}{$10-15$} & Pulp & $3.9 \pm 0.3$ & 5.490 & \pm & $0.003^{\mathrm{c}}$ & 0.981 & \pm & $0.003^{c}$ \\
\hline & Peel & & 2.157 & \pm & $0.008^{b}$ & 0.976 & \pm & $0.008^{b}$ \\
\hline & Seed & & 0.722 & \pm & $0.005^{\mathrm{a}}$ & 0.958 & \pm & $0.005^{\mathrm{a}}$ \\
\hline \multirow{3}{*}{$15-20$} & Pulp & $3.9 \pm 0.2$ & 4.8 & \pm & $0.5^{\mathrm{c}}$ & 0.980 & \pm & $0.005^{\mathrm{c}}$ \\
\hline & Peel & & 1.8 & \pm & $0.4^{\mathrm{b}}$ & 0.9659 & \pm & $0.0098^{\mathrm{b}}$ \\
\hline & Seed & & 0.7 & \pm & $0.2^{\mathrm{a}}$ & 0.955 & \pm & $0.005^{\mathrm{a}}$ \\
\hline \multirow{3}{*}{$20-25$} & Pulp & $3.5 \pm 1.4$ & 5.1 & \pm & $0.6^{\mathrm{c}}$ & 0.981 & \pm & $0.003^{c}$ \\
\hline & Peel & & 1.9 & \pm & $0.4^{b}$ & 0.967 & \pm & $0.006^{\mathrm{b}}$ \\
\hline & Seed & & 0.67 & \pm & $0.19^{\mathrm{a}}$ & 0.9526 & \pm & $0.0096^{\mathrm{a}}$ \\
\hline
\end{tabular}

Different letters (a-c) indicate significant difference among values of each tissue according to each MI with $p<0.05$. 
Table 2. Relaxation dielectric constant at each specific dispersion $(\alpha, \beta$ and $\gamma)$.

\begin{tabular}{|c|c|c|c|c|c|c|c|c|c|c|}
\hline \multirow[b]{2}{*}{ MI } & \multirow[b]{2}{*}{ Tissue } & \multicolumn{9}{|c|}{$\varepsilon^{\prime}$} \\
\hline & & \multicolumn{3}{|c|}{$\alpha\left(\cdot 10^{4}\right)$} & \multicolumn{3}{|c|}{$\beta\left(\cdot 10^{2}\right)$} & \multicolumn{3}{|c|}{$\gamma$} \\
\hline \multirow{3}{*}{$10-15$} & Pulp & 345 & \pm & $50^{\mathrm{a}}$ & 11 & \pm & $2^{\mathrm{a}}$ & 34.6 & \pm & $0.92^{\mathrm{a}}$ \\
\hline & Peel & 5 & \pm & $0.4^{\mathrm{b}}$ & 1.8 & \pm & $0.15^{\mathrm{b}}$ & 16 & \pm & $4^{\mathrm{b}}$ \\
\hline & Seed & 18 & \pm & $6^{\mathrm{b}}$ & 3 & \pm & $1^{\mathrm{b}}$ & 11 & \pm & $3^{\mathrm{c}}$ \\
\hline \multirow{3}{*}{$15-20$} & Pulp & 304 & \pm & $56^{\mathrm{a}}$ & 13 & \pm & $4^{\mathrm{a}}$ & 34.2 & \pm & $0.8^{\mathrm{a}}$ \\
\hline & Peel & 17 & \pm & $13^{\mathrm{b}}$ & 2.1 & \pm & $0.5^{\mathrm{b}}$ & 15 & \pm & $4^{b}$ \\
\hline & Seed & 20 & \pm & $8^{\mathrm{b}}$ & 2 & \pm & $1^{\mathrm{b}}$ & 10 & \pm & $3^{c}$ \\
\hline \multirow{3}{*}{$20-25$} & Pulp & 356 & \pm & $158^{\mathrm{a}}$ & 12 & \pm & $3^{\mathrm{a}}$ & 34 & \pm & $1^{\mathrm{a}}$ \\
\hline & Peel & 6 & \pm & $2^{\mathrm{b}}$ & 1.6 & \pm & $0.3^{\mathrm{b}}$ & 15 & \pm & $2^{\mathrm{b}}$ \\
\hline & Seed & 13 & \pm & $10^{\mathrm{b}}$ & 2 & \pm & $1^{\mathrm{b}}$ & 10 & \pm & $3^{\mathrm{c}}$ \\
\hline
\end{tabular}

Different letters (a-c) indicate difference among values of each tissue according to each MI with $p<0.05$. 
Table 3. Relaxation frequency at each specific dispersion $(\alpha, \beta$ and $\gamma)$.

\begin{tabular}{|c|c|c|c|c|c|c|c|c|c|c|}
\hline & & \multicolumn{9}{|c|}{$f$} \\
\hline MI & Tissue & \multicolumn{3}{|c|}{$\alpha(\mathrm{kHz})$} & \multicolumn{3}{|c|}{$\beta(\mathrm{MHz})$} & \multicolumn{3}{|c|}{$\gamma(\mathrm{GHz})$} \\
\hline \multirow{3}{*}{$10-15$} & Pulp & 0.4 & \pm & $0.3^{\mathrm{c}}$ & 0.9 & \pm & $0.1^{\mathrm{b}}$ & 20 & \pm & $3^{\mathrm{a}}$ \\
\hline & Peel & 6.2 & \pm & $0.7^{\mathrm{a}}$ & 2.2 & \pm & $0.5^{\mathrm{a}}$ & 22 & \pm & $4^{\mathrm{a}}$ \\
\hline & Seed & 3 & \pm & $1^{\mathrm{b}}$ & 1.2 & \pm & $0.4^{\mathrm{ab}}$ & 18 & \pm & $4^{\mathrm{a}}$ \\
\hline \multirow{3}{*}{$15-20$} & Pulp & 0.4 & \pm & $0.2^{\mathrm{c}}$ & 0.597 & \pm & $0.093^{b}$ & 18 & \pm & $3^{\mathrm{a}}$ \\
\hline & Peel & 5 & \pm & $2^{\mathrm{a}}$ & 2 & \pm & $0.7^{\mathrm{a}}$ & 24 & \pm & $4^{\mathrm{a}}$ \\
\hline & Seed & 4 & \pm & $2^{\mathrm{b}}$ & 1.90 & \pm & $0.5^{\mathrm{ab}}$ & 19 & \pm & $2^{\mathrm{a}}$ \\
\hline \multirow{3}{*}{$20-25$} & Pulp & 0.5 & \pm & $0.3^{c}$ & 0.63 & \pm & $0.11^{\mathrm{b}}$ & 18 & \pm & $2^{\mathrm{a}}$ \\
\hline & Peel & 8 & \pm & $1^{\mathrm{a}}$ & 2 & \pm & $0.3^{\mathrm{a}}$ & 25 & \pm & $5^{\mathrm{a}}$ \\
\hline & Seed & 4.2 & \pm & $0.9^{\mathrm{b}}$ & 2 & \pm & $0.2^{\mathrm{ab}}$ & 19 & \pm & $2^{\mathrm{a}}$ \\
\hline
\end{tabular}

Different letters (a-c) indicate significant difference among values of each tissue according to each MI with $p<0.05$. 